\title{
Review of High Relative Humidity in Catheter Laboratory of a Private Hospital and a Low Energy Consuming Solution
}

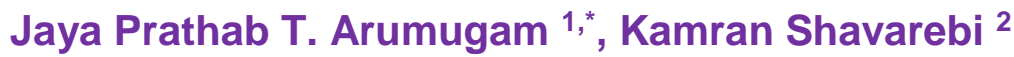

${ }^{1}$ Faculty of Arts \& Science, International University of Malaya-Wales, Kuala Lumpur, Malaysia

${ }^{2}$ Associate Professor, Faculty of Arts \& Science, International University of Malaya-Wales, Kuala Lumpur, Malaysia

${ }^{*}$ Corresponding author Ph: +60193363561; Email: jprathab@yahoo.com

DOI: https://doi.org/10.34256/irjmt2122

Received: 23-02-2021, Revised: 27-02-2021, Accepted: 28-02-2021, Published: 01-03-2021

Abstract: The Relative Humidity in a Catheter Laboratory is desirous to be controlled within a range of 30 to $65 \%$ $\mathrm{RH}$. A maximum Relative Humidity $(\mathrm{RH})$ fluctuation of up to $70 \%$ is tolerated. A case study is presented whereby a high $\mathrm{RH}$ of up to $80 \% \mathrm{RH}$ has been recorded in the examination room of a Catheter Laboratory (CathLab) in a local Hospital. The conditioned air to the CathLab is supplied through an existing dedicated Chilled Water Air Handling Unit. Two (2) solutions were considered and the technical and commercial comparisons carried out. The first option is an inline dehumidifier system and the second option is to install a portable standalone dehumidifier inside the CathLab examination room. Solutions to address the high Relative Humidity have to be carefully considered as the introduction of in-line dehumidifiers contribute to higher energy consumption. The latter was selected based on commercial reasons. Three (3) weeks of $\mathrm{RH}$ monitoring via the building's Integrated Building Management System (IBMS) was carried out. The readings measured show a drastic reduction in $\mathrm{RH}$ to a mean of about $60 \% \mathrm{RH}$ which meets the end user's requirement. The cost for the second option was also found to be much lower at about $10 \%$ of the first option.

Keywords: Dry Bulb, Wet Bulb, Moisture, Relative Humidity, Energy.

\section{Introduction}

It is imperative to maintain good Indoor Air Quality (IAQ) in hospitals as inappropriate IAQ can encourage the growth of contaminants such as moulds and fungi [1]. In addition, communicable diseases and viral infections are further accelerated by bad IAQ. Generally, the properties of Indoor Air Quality shall be as shown in the table 1.

The optimum dry bulb temperature and Relative Humidity range in the Cathlab is $18{ }^{\circ} \mathrm{C}$ to $24^{\circ} \mathrm{C}$ and 30 to $70 \% \mathrm{RH}$. However, specific rooms in the healthcare facility will have more stringent requirements such as Operation Theatres, Imaging Departments and Pharmacy. The Staff also spends long hours within the hospital environment and as such it is important that the IAQ is maintained within the recommended ranges at all times [2].

The ratio of the partial pressure of water vapor to the equilibrium vapor pressure of water at a given temperature is termed Relative Humidity $(\mathrm{RH})$ and is normally expressed as a percentage [3].
When the percentage is high, there is high moisture content in the air and the air is termed humid [4]. At $100 \% \mathrm{RH}$, the air is termed to be saturated and it cannot absorb any more moisture, it has reached its dew point. Any addition of moisture will cause condensation. High $\mathrm{RH}$ in Hospital environment is detrimental to various functions including the operation of the Imaging Equipment and damage to the electronic components of the machine becomes a risk [5].

Psychrometry is the science of studying the thermodynamic properties of moist air [6]. The amount of moisture vapour in the air varies quite significantly under different conditions. When the air is hot, it can contain a large amount of moisture vapour. When it is cold, its capacity to hold the moisture is reduced [7]. When the temperature of warm air begins to fall, the vapour also cools and, if cooling continues, it will condense into tiny moisture droplets. In the atmosphere this results in the formation of clouds and eventually rain. 
Table 1 Acceptable Range of IAQ parameters in accordance to Industry Code of Practice (ICOP) on Indoor Air Quality 2010

\begin{tabular}{|c|l|l|}
\hline No & Parameters & Acceptable Range / Limit \\
\hline & Physical Parameters & \\
\hline 1. & Air Temperature & $23-26^{\circ} \mathrm{C}$ \\
\hline 2. & Relative Humidity & $40-70 \%$ \\
\hline 3. & Air Movement & $0.15-0.50 \mathrm{~m} / \mathrm{s}$ \\
\hline & Indoor Air Contaminants & \\
\hline & Chemical Contaminants & \\
\hline 1. & Carbon Monoxide & $10 \mathrm{ppm}$ \\
\hline 2. & Formaldehyde & $0.1 \mathrm{ppm}$ \\
\hline 3. & Ozone & $0.05 \mathrm{ppm}$ \\
\hline 4. & Respirable Particulates & $0.15 \mathrm{mg} / \mathrm{m}^{3}$ \\
\hline 5. & Total Volatile Organic Compounds (TVOC) & $3 \mathrm{ppm}$ \\
\hline & Biological Contaminants & \\
\hline 1. & Total Bacterial Counts & $500 \mathrm{cfu} / \mathrm{m}^{3}$ \\
\hline 2. & Total Fungal Counts & $1000 \mathrm{cfu} / \mathrm{m}^{3}$ \\
\hline & Ventilation Performance Indicator & \\
\hline 1. & Carbon Dioxide & $1000 \mathrm{ppm}$ \\
\hline
\end{tabular}

The psychrometric chart generally is used to determine the following five (5) parameters of the airwater vapour mixtures [8].

- Dry Bulb Temperature

- Wet Bulb Temperature

- Dewpoint Temperature

- Relative Humidity

- Humidity Ratio

By plotting any two (2) parameters, the other three (3) parameters can be determined by using the psychrometric chart. Whenever either the heat content or moisture content of air is changed, the point on the psychrometric chart that represents the initial condition of the air moves in a straight line to a position that represents the new condition of temperature and/or humidity. The objective of this study is to withdraw moisture while keeping the dry bulb temperature constant and is termed dehumidification.

Dehumidification can be achieved generally by two (2) processes:

- Desiccant Dehumidification and

- Mechanical Dehumidification [9]

Desiccant Dehumidification is also known as Chemical Dehumidification. In this process, desiccants are used to remove moisture in the supply air stream.

Mechanical dehumidification utilises the air conditioning processes by cooling the air beyond the saturation temperature of the supply air.
Cooling beyond this temperature, will make the moisture condense out of the air stream thus lowering the absolute humidity. Subsequently, the air is heated to room temperature when the dehumidified air absorbs the various internal and external room heat loads. The effect is a low Relative Humidity in the room [10].

\section{Problem Statement}

The Cathlab in the private Hospital was experiencing high maximum $\mathrm{RH}$ up to $80 \%$. The Client's requirement is between $30 \%$ and $70 \%$. This high $\mathrm{RH}$ is not conducive for a Cathlab environment and the staff working there [11]. Whether it is about proper handling and storage of drug-eluting stents, plasma supplies, or protecting anticoagulants from humidity-caused deterioration, there is a wide range of drugs and other supplies in the typical Cathlab that need to be protected from adverse temperature and/or humidity effects [12]. The existing airconditioned supply air is supplied via a Chilled Water Air Handling Unit. The initial dry bulb temperature and $\mathrm{RH}$ during the Testing \& Commissioning stage recorded temperatures below $22{ }^{\circ} \mathrm{C}$ and $\mathrm{RH}$ of between 60 to $70 \%$. After about 5 years in operation, the dry bulb temperature maintained but the $\mathrm{RH}$ began to rise. As it is imperative to generally maintain the $\mathrm{RH}$ between 30 to $65 \% \mathrm{RH}$, the Client is keen to review the Chilled Water system architecture with a view of retrofit to ensure the $\mathrm{RH}$ is maintained within the range. 


\section{Methods}

The retrofit was to be designed with a low commercial impact and to be implemented with minimum disruption to the operation of the Cathlab. To do this, two (2) Options were studied namely Inline Dehumidifier System and Portable Dehumidifiers (Table 2).

\subsection{Option 1 - Inline Dehumidifier System}

\subsubsection{Technical proposal}

An inline dehumidifier system was proposed to be installed in the existing Chilled Water Supply System [10]. Figure 1 shows the system flow diagram. Psychrometry is used to determine the dry bulb temperature, relative humidity and absolute humidity at each stage. $10 \%$ Fresh air amounting to $510 \mathrm{cmh}$ was introduced through a pre-cooling Chilled Water Fan Coil Unit (FCU). The outdoor conditions are $35^{\circ} \mathrm{C}$ Dry Bulb and $27^{\circ} \mathrm{C}$ Wet Bulb. Moisture content of the outside air is $20.3 \mathrm{~g} / \mathrm{kg}$. This air is run through a pre-cooling Chilled Water Fan Coil Unit of capacity 30,196 Btu/Hr to condition the air to $12.8^{\circ} \mathrm{C}$ Dry Bulb temperature and $12.2^{\circ} \mathrm{C}$ wet bulb temperature and a reduced moisture content of $8.5 \mathrm{~g} / \mathrm{kg}$. Subsequently, the fresh air is passed through a Desiccant type dehumidifier where the Relative Humidity is further reduced to $3.7 \% \mathrm{RH}$. This fresh air is mixed with the return air from the Cathlab room. The $90 \%$ return air characteristics is $19^{\circ} \mathrm{C}$ Dry Bulb temperature and moisture content of 7.4 $\mathrm{g} / \mathrm{kg}$.
The mixed return air is computed to achieve $21.2^{\circ} \mathrm{C}$ Dry Bulb temperature and moisture content of $6.8 \mathrm{~g} / \mathrm{kg}$. This mixed air is conditioned in the centralized chilled water AHU to achieve off-coil condition of $12.8^{\circ} \mathrm{C}$ Dry Bulb temperature and moisture content of $6.8 \mathrm{~g} / \mathrm{kg}$ and supplied to the space. In the conditioned space, the Cathlab room, the supply air picks up the heat and the resultant condition is $19^{\circ} \mathrm{C}$ Dry Bulb temperature, $\mathrm{RH}$ of 55 to $70 \%$ and Absolute humidity of $7.4 \mathrm{~g} / \mathrm{kg}$. This satisfies the requirement of the Client.

\subsubsection{Commercial proposal}

The estimated cost is given in table 3 .

Table 3 Estimated Cost of Supply and Installation of Equipment

\begin{tabular}{|l|l|r|}
\hline No & Description & $\begin{array}{l}\text { Estimated } \\
\text { Cost (RM) }\end{array}$ \\
\hline 1 & $\begin{array}{l}\text { Chilled water FCU and } \\
\text { accessories }\end{array}$ & $20,000.00$ \\
\hline 2 & $\begin{array}{l}\text { Modification to existing } \\
\text { ductwork and new ductwork }\end{array}$ & $6,000.00$ \\
\hline 3 & Desiccant Dehumidifier & $30,000.00$ \\
\hline 4 & Power supply & $3,000.00$ \\
\hline & Total & $\mathbf{5 9 , 0 0 0 . 0 0}$ \\
\hline
\end{tabular}

Table 2 Specifications of Inline Dehumidifier

COMPACT DEHUMIDIFER - FFB SERIES - SPECIFICATIONS

\begin{tabular}{|l|c|}
\hline \multicolumn{1}{|c|}{ MODEL } & FFB 600 \\
\hline Process Air Flow $(\mathrm{cmh})$ & 600 \\
\hline Process ESP $(\mathrm{Pa})$ & 200 \\
\hline Processs Motor $(\mathrm{kW})$ & 0.37 \\
\hline React Air Flow $(\mathrm{cmh})$ & 200 \\
\hline React ESP $(\mathrm{Pa})$ & 150 \\
\hline React Motor $(\mathrm{kW})$ & 0.37 \\
\hline React Heater $(\mathrm{kW})$ & 7.2 \\
\hline Power Required $(\mathrm{V} / \mathrm{Ph} / \mathrm{Hz})$ & $415 / 3 / 50$ \\
\hline Approx Weight $(\mathrm{kg})$ & 109 \\
\hline Dimensions $(\mathrm{LxDxH}) \mathrm{mm}$ & $890 \times 630 \times 494$ \\
\hline
\end{tabular}




\subsubsection{Encumbrances}

The various encumbrances envisaged are as follows:

i) The existing ductwork need to be modified and new ductwork and equipment installed. This requires the Cathlab to be shut down for at least 2 weeks.

ii) The power supply requirement is $7.9 \mathrm{~kW}$ for the new equipment amounting to an additional RM 10,000 per annum.

iii) The capital cost is RM 59,000.

The specifications of the equipment is listed

\subsection{Option 2 - Portable Dehumidifiers}

The Cathlab is being operated full time and any downtime will be detrimental to the operation of the Cathlab. Thus, an Option 2 is considered, whereby a portable standalone dehumidifier is proposed to be installed within the room. The design of this system is shown below:

A Standalone Dehumidifier was selected based on the moisture removal capacity required (Table 4 \&5). below:

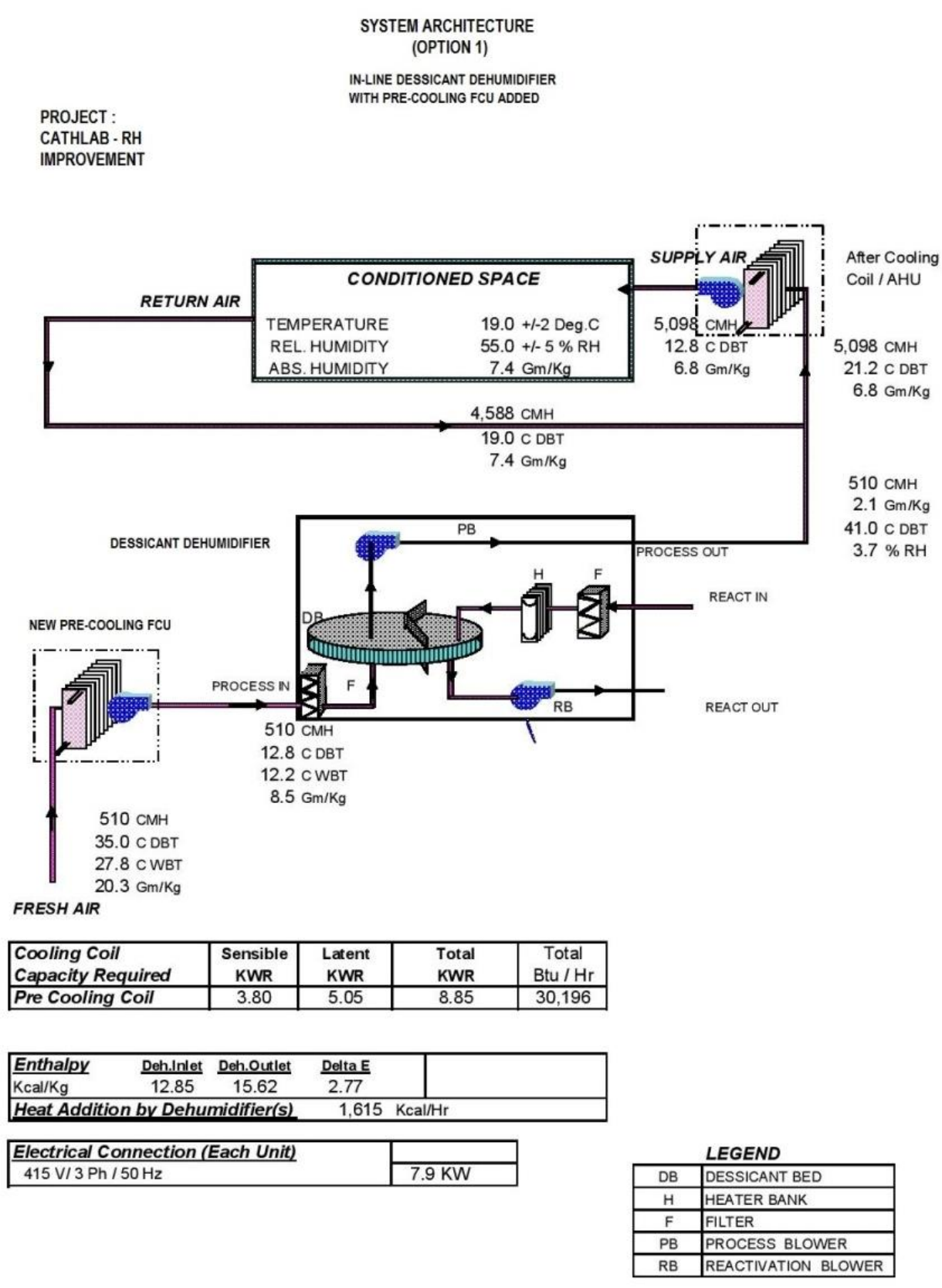

Figure 1 System Architecture of Inline Dehumidifier Installation System (Option 1) 
Table 4 RH Load Estimation for Standalone Portable Dehumidifier

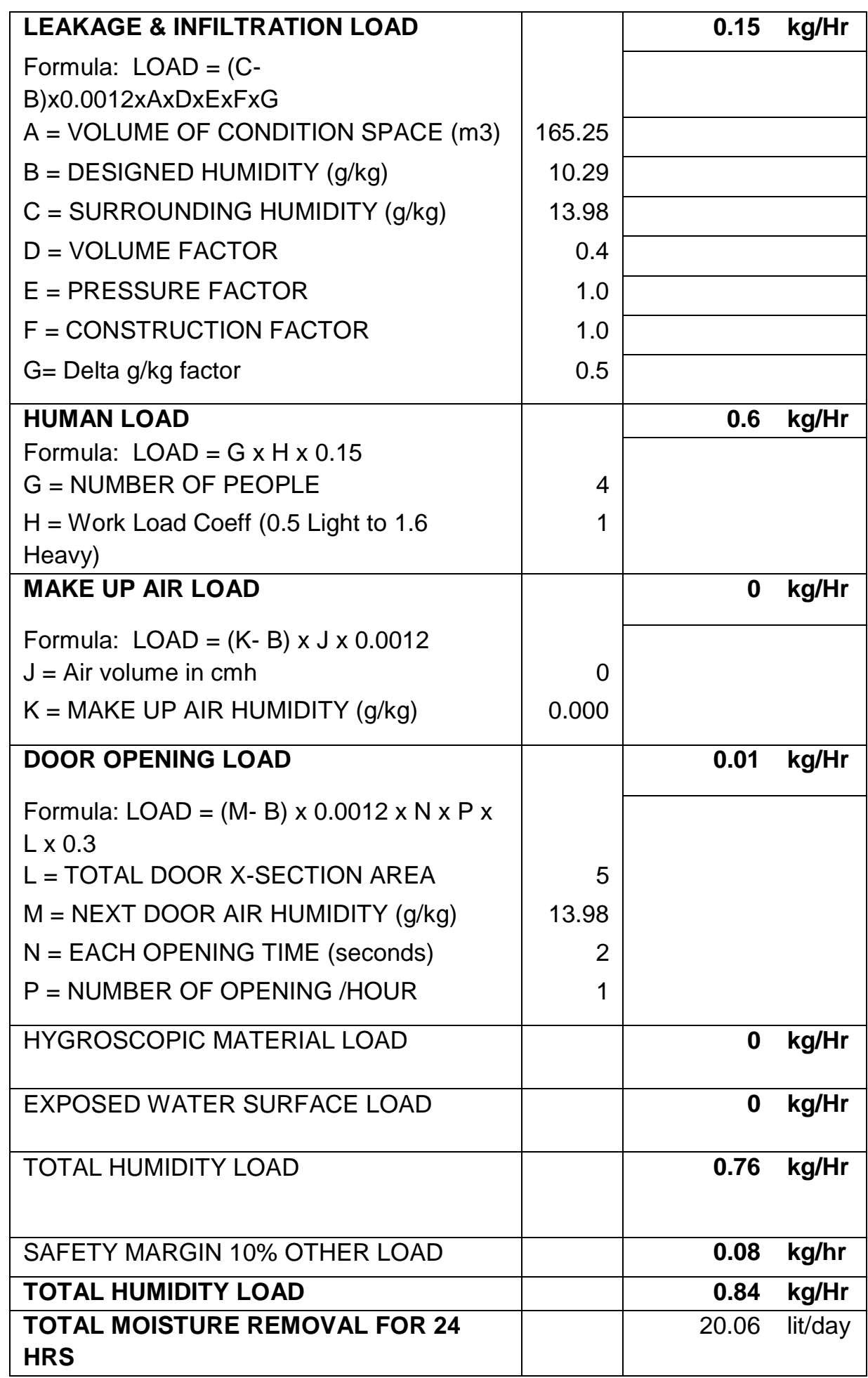


Table 5 Specifications of Standalone Dehumidifier

\begin{tabular}{|c|c|}
\hline \multicolumn{2}{|l|}{ Capacity } \\
\hline $\begin{array}{l}\text { Moisture Removal capacity } \\
\left(30^{\circ} \mathrm{Cl} 80 \% \mathrm{RH}\right)\end{array}$ & 90 liters/Day \\
\hline Water Tank Capacity & $\mathrm{n} / \mathrm{a}$ \\
\hline Operating Temperature & $5^{\circ} \mathrm{C}-35^{\circ} \mathrm{C}$ \\
\hline \multicolumn{2}{|l|}{ Features } \\
\hline Compressor Type & Rotary \\
\hline Refrigerant & R410A \\
\hline Front Mount Reservoir & Direct \\
\hline Water level Indicator & Direct \\
\hline Continuous drain out option & Yes \\
\hline Drain hose connection & Yes \\
\hline Washable air Filter & Yes \\
\hline Casters & Yes \\
\hline Convenient handle & No \\
\hline Automatic defrost when reservoir full & Yes \\
\hline Electronic control & Yes \\
\hline Soft Key button & Yes \\
\hline Display Screen & LED \\
\hline Microprocessor self check at startup & Yes \\
\hline Adjustable dehumidifier control display & Yes \\
\hline Fan Speed & 2 \\
\hline Auto timer ON-OFF & Yes \\
\hline \multicolumn{2}{|l|}{ Energy } \\
\hline Power Supply & $230 \mathrm{~V} / 1 \mathrm{Ph} / 50 \mathrm{~Hz}$ \\
\hline Power Consumption (W) & 1350 \\
\hline Maximum current $(\mathrm{A})$ & 5.9 \\
\hline \multicolumn{2}{|l|}{ Dimension } \\
\hline Dimension $(\mathrm{W} \times \mathrm{H} \times \mathrm{D}) \mathrm{mm}$ & $480 \times 440 \times 970$ \\
\hline Ney Weight $(\mathrm{kg})$ & 45 \\
\hline
\end{tabular}

\subsubsection{Advantages}

The various advantages for using Option 2 are listed as follows:

i. The existing ductwork need not be modified. This does not require the Cathlab to be shut down. No downtime.

ii. The power supply requirement is $1.5 \mathrm{~kW}$ for the new equipment amounting to an additional RM 1,200 per annum.

iii. The capital cost is RM 6,000.

\section{Testing and commissioning of the equipment}

The standalone portable dehumidifier was installed in the premises for a period of 3 weeks and the $\mathrm{RH}$ data log recorded by the centralised Building Management System was reviewed. The log is as listed below.

By plotting a chart of average $\mathrm{RH}$ value by date, the difference made by the portable dehumidifier can be very clearly seen.

\section{Conclusion}

This study presents a review of two (2) options of different dehumidification systems adopted to lower the $\mathrm{RH}$ in a CathLab. The first Option is a more costly option whereas the second option is a much cheaper option. The capital cost and operation cost of the two (2) options is presented below

\begin{tabular}{|l|c|c|}
\hline Options & $\begin{array}{l}\text { Capital } \\
\text { Cost (RM) }\end{array}$ & $\begin{array}{l}\text { Operation } \\
\text { Cost (RM per } \\
\text { annum) }\end{array}$ \\
\hline $\begin{array}{l}\text { Inline } \\
\text { Dehumidifier } \\
\text { System }\end{array}$ & $59,000.00$ & $10,000.00$ \\
\hline $\begin{array}{l}\text { Portable } \\
\text { Dehumidifiers }\end{array}$ & $6,000.00$ & $1,200.00$ \\
\hline
\end{tabular}

Based on the cost, the second option was adopted and the equipment installed at site. It can also be seen from the data log that the RH for Option 2 has reduced to below $70 \%$ and meets the Client's requirement at an economical cost. This solution is a low capital cost and low energy consuming answer to the problem statement. In the era of global financial constraint, it is pertinent that capital expenses be kept low albeit not compromising on system performance. System designers have to be innovative and explore various options to ensure the end performance criteria is met at a competitive cost. In this case study, it can be seen that a simple low-cost solution can meet the same requirements as a comprehensive system.

\section{References}

[1] Engineering Services Division, Guideline on Mould Control and Remediation in Healthcare Facilities. (2016).

https://www.scribd.com/document/386978214/Htf QuGuideline-on-Mould-Control-Remediation-InHealthcare-Facilities-October-2016-pdf

Accessed on December 2020.

[2] K. Aini Mohd Sari, K. Farhah Almar Mastaza, M. Ashraf Abdul Rahman, N. Saji, R. Muslim, M. Syafiq Syazwan Mustafa, \& T. Yean Ghing, Assessment of indoor air quality parameters at Ambulatory Care Centre XYZ, Malaysia, IOP Conference Series: Earth and Environmental Science, 373(1) (2019). https://doi.org/10.1088/1755-1315/373/1/012013

[3] C.W. Callahan, A.M. Elansari, \& D.L. Fenton, (2019). Psychrometrics. In Postharvest Technology of Perishable Horticultural Commodities (pp. 271-310). https://doi.org/10.1016/B978-0-12-813276$\underline{0.00008-0}$

[4] S. Sattayakorn, M. Ichinose, \& R. Sasaki, Clarifying thermal comfort of healthcare 
occupants in tropical region: A case of indoor environment in Thai hospitals, Energy and Buildings, 149 (2017) 45-57.

https://doi.org/10.1016/j.enbuild.2017.05.025

[5] Fouras, M.J. Kitchen, S. Dubsky, R.A. Lewis, S.B. Hooper, \& K. Hourigan, The past, present, and future of $x$-ray technology for in vivo imaging of function and form, Journal of Applied Physics, 105(10) (2009).

https://doi.org/10.1063/1.3115643

[6] D. Meyer, \& D. Thevenard, PsychroLib: a library of psychrometric functions to calculate thermodynamic properties of air, Journal of Open Source Software, 4(33) (2019) 1137.

https://doi.org/10.21105/joss.01137

[7] M. Ahmadzadehtalatapeh, \& Y. H. Yau, Assessment of climate change impact on the required cooling load of the hospital buildings, Journal of Engineering Science and Technology, 12(8) (2017) 2091-2105.

[8] H. Ren, Construction of a Generalized Psychrometric Chart for Different Pressures, International Journal of Mechanical Engineering Education, 32(3) (2004) 212-222. https://doi.org/10.7227/IJMEE.32.3.3

[9] M.H. Mahmood, M. Sultan, \& T. Miyazaki, Solid desiccant dehumidification-based air-conditioning system for agricultural storage application: Theory and experiments, Proceedings of the Institution of Mechanical Engineers, Part A: Journal of Power and Energy, 234(4) (2020) 534-547.

\section{https://doi.org/10.1177/0957650919869503}

[10] Purushothama, (2009). Humidification and Ventilation Management in Textile Industry, Elsevier.

[11] N.C. Burton, Evaluation of Indoor Environmental Quality Concerns Among Hospital Employees Working in a Radiology Department. $\mathrm{NIOSH}$ health hazard evaluation report, (2018). https://stacks.cdc.gov/view/cdc/76247 Accessed on December 2020.

[12] I.S. Kurniawansyah, M. Abdassah, \& S. Gondodiputro, Relationship between Temperature and Humidity on Sterility of Reusable Instruments in Hospital's CSSD, International Journal of Pharmaceutical Sciences Review and Research, 33(2) (2015) 215-219.

\section{Funding}

No funding was received for conducting this study.

\section{Conflict of interest}

The authors have no conflicts of interest to declare that they are relevant to the content of this article.

\section{About the License}

(C) The author(s) 2021. The text of this article is open access and licensed under a Creative Commons Attribution 4.0 International License

\section{Cite this Article}

Jaya Prathab T. Arumugam, Kamran Shavarebi, Review of High Relative Humidity in Catheter Laboratory of a Private Hospital and a Low Energy Consuming Solution, International Research Journal of Multidisciplinary Technovation, Vol 3, Iss 2 (2021) 7-13.

DOI: https://doi.org/10.34256/irimt2122 